\title{
PERCUTANEOUS ENDOSCOPIC GASTROSTOMY IN ADVANCED HEAD AND NECK CANCER
}

\author{
Gastrostomia endoscópica percutânea em pacientes com tumores avançados de \\ cabeça e pescoço
}

\author{
Paulo Moacir de Oliveira CAMPOLI, Flávio Hayato EJIMA, Daniela Medeiros Milhomem CARDOSO, \\ Paulo Adriano de Queiroz BARRETO, Rafael de Deus PIRES, Alexandre João MENEGHINI, \\ Maria Paula CURADO, José Carlos de OLIVEIRA, Orlando Milhomem da MOTA
}

ABCDDV/536

Campoli PMO, Ejima FH, Cardoso DMM, Barreto PAQ, Pires RD, Meneghini AJ, Curado MP, Oliveira JC, Mota OM. Percutaneous endoscopic gastrostomy in advanced head and neck cancer. ABCD Arq Bras Cir Dig 2007; 20(2):97-101.

ABSTRACT - Background - Percutaneous endoscopic gastrostomy performed as proposed by Gauderer et al. in 1980, has been used quite frequently in patients with head and neck tumors. Some authors believe that this so-called pull technique would be associated to the risk of a tumor implantation in the wound as well as high levels of peristomal wound infection. Although some alternative techniques provide better results, doubts about their technical applicability in daily practice still persists. Aim - To assess the feasibility, safety and morbidity of percutaneous endoscopic gastrostomy performed through a well-defined and standardized technique in patients with nonresectable or advanced head and neck cancer. Methods - A consecutive series of patients who had either nonresectable or advanced tumors and were unable to be fed orally were submitted to an oncologichospital-based tertiary-referral endoscopy practice. Tubes were implanted through an introducer technique comprised of two main stages. The first consisted of the application of two stitches aiming to fixate the anterior gastric wall to the abdominal wall, and the second being the inserting of the gastrostomy tube. Results - Between February 2003 and May 2004, 129 percutaneous endoscopic gastrostomies were performed. This study included 60 patients. They were all able to receive food on the same day. Operative morbidity was observed in six patients (10\%) and one procedure-related mortality was also observed (1.6\%). Conclusion - Percutaneous endoscopic gastrostomy is both feasible and safe, associated to low morbidity, and to acceptable mortality rates.

HEADINGS - Video-assisted surgery. Head and neck neoplasms. Gastrostomy. Suture techniques.

\section{INTRODUCTION}

Patients with head and neck tumors are frequently unable to receive food through the mouth. This condition causes a nutritional deficit and contributes to therapy failure. Gastrostomy performed percutaneously with the aid of endoscopy has become the choosen procedure rather than conventional surgical gastrostomy due to being easier, safer and with less morbidity. Percutaneous endoscopic gastrostomy (PEG) is widely executed throughout the world by means of the pull technique, as proposed by Gauderer et al., in $1980^{10}$. This PEG technique is relatively simple to perform, especially when commercially available kits are used. However, it has inherent problems caused by the passage of the gastrostomy tube through the oral cavity. Some complications are the high risk of peristomal wound infection ${ }^{11}$ and the risk, however small, of tumor implantation in the gastrostomy site, when the procedure is performed in patients with head and neck cancers ${ }^{1}$. Additionally, these kits are expensive ${ }^{13}$, especially for the low income population, and the Unified Brazilian

Trabalho realizado no Hospital Araújo Jorge de Goiás - Associação Contra o Câncer, Goiânia, Goiás, Brasil.

Endereço para correspondência: Paulo Moacir de Oliveira Campoli, e-mail: paulomar@ih.com.br
Public Health System - SUS does not provide for the reimbursement of this material.

Several authors have proposed a variety of alternatives, aiming the reduction of peristomal infection risk ${ }^{5}$, of which decrease the already low risk of tumor implantation in the gastrostomy $\operatorname{site}^{28}$, and use resources which reduce procedure $\cos ^{13}$. However, doubts persist with regards to these technical variants. An important concern is if they are adequate for routine use, since they are more technically complex.

The aim of the present study was to assess the feasibility, safety and morbidity of a PEG performed through a well-defined standardized technique, described below, in patients with nonresectable recurrences or advanced tumors of the head and neck, who were unable to eat.

\section{METHODS}

Since February 2003, patients who needed a PEG from our institutions had their tubes implanted through a two-stage standardized technique. The first stage consisted of the application of two stitches aiming to fixate the anterior gastric wall to the abdominal wall, and the second, consisted of the introducer technique, used to insert the gastrostomy tube. 
After the endoscopy, the patient was placed in the supine position and once the stomach was adequately insufflated, the insertion point was identified by transillumination and palpation of the abdominal wall.

Using an aseptic technique along with topical anesthesia with lidocaine, two punctures of about $3 \mathrm{~cm}$ apart were made with long needles $\left(\mathrm{JELCO}^{\circledR}\right.$ I.V. Catheter $14 \mathrm{G}$ - Medex Medical Ltd, Rossendale, Lancashire, UK) that perforated the abdominal and the gastric walls. One of the needles contained a 2-0 nylon thread that came out from the inserted extremity. The other needle contained a 2-0 nylon thread loop that also came out from the extremity (Figure 1a). With a snare, the nylon thread was brought through the nylon loop (Figure $1 \mathrm{~b}$ and $1 \mathrm{c}$ ) that grasped the nylon thread and brought it back to the skin surface (Figure 1d) in such a way as to obtain a transfixion stitch in "U". This procedure was then repeated in order to obtain a second parallel stitch, $2 \mathrm{~cm}$ apart from the first stitch (Figure 1e), being the same suture method proposed in 1999 by Kiser et al. ${ }^{18}$.
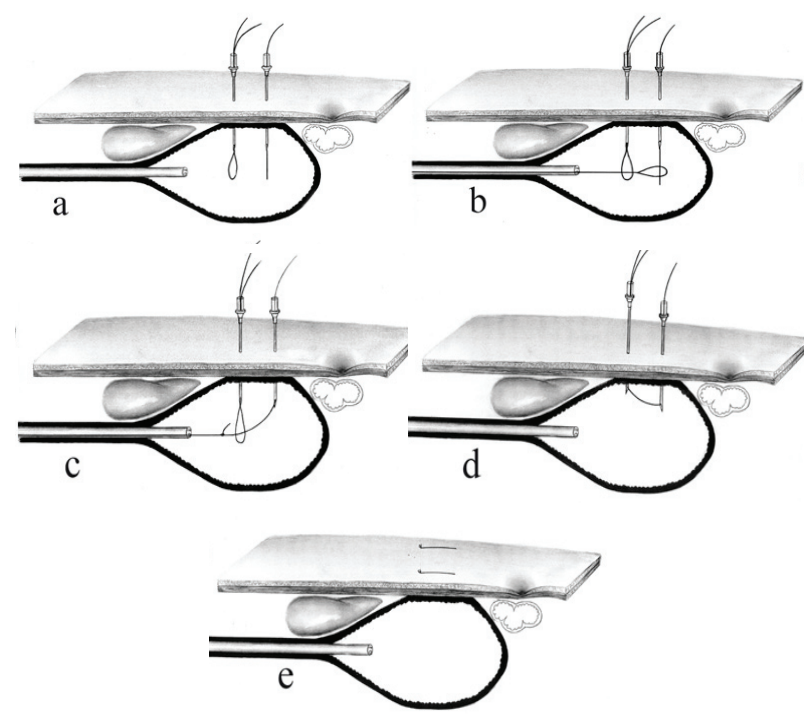

FIGURE 1 - Two long needles are used to puncture the gastric wall (a). The loose thread is attached by the snare (b) and brought into the loop (c). The loose thread is held by the loop and brought back to the skin (d) in order to make a transfixion stitch in the form of a " $U$ ". This procedure is repeated to make another stitch beside the first one (e)

The stomach having been properly fixated to the abdominal wall by means of the two stitches, a cutaneous incision was made between them (Figure 2a). Then, curved Metzenbaum scissors (Figure $2 b$ ) were used to dissect the abdominal wall, thereby creating a path towards the gastric wall.

The next step was to puncture the gastric lumen using a trocar introducer with a peel-away sheath (Figures $3 a$ and $3 b$ ) which allowed the insertion of the gastrostomy tube through the sheath (Figure 3c) and the total removal as well (Figure 3d). Latex Foley 16 Fr. catheters were used in each case.

All the procedures were performed by two doctors in the
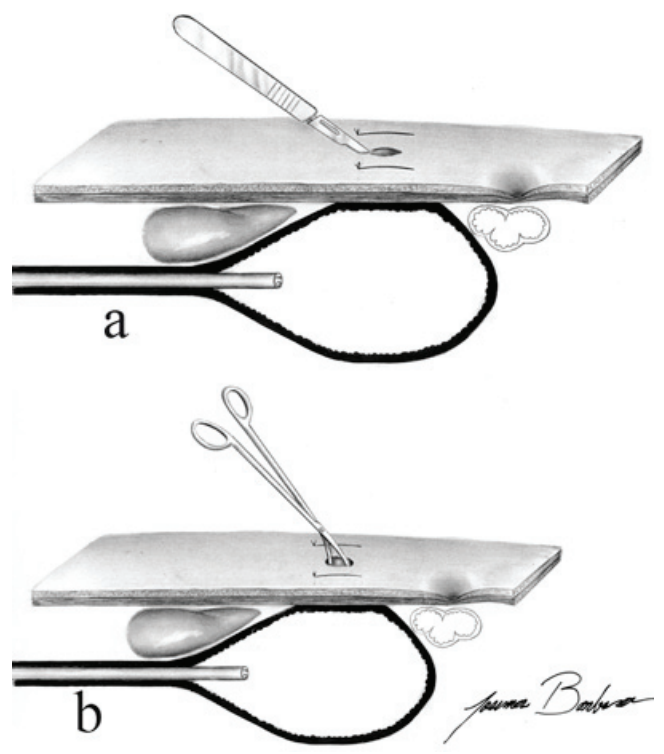

FIGURE 2 - A cutaneous incision is made between the two stitches (a) and afterwards a path is made through the abdominal wall by using Metzenbaum scissors without puncturing the gastric wall (b).
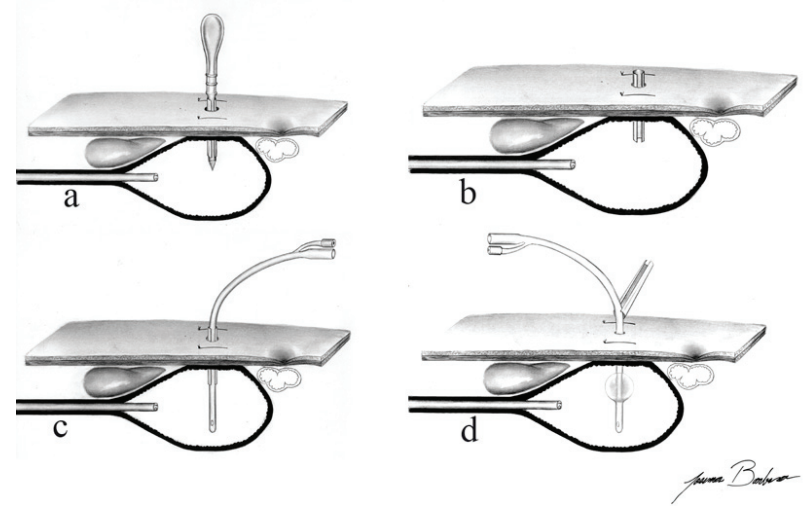

FIGURE 3 - The gastric wall is punctured with a trocar introducer with a peel-away sheath ( $a$ and $b$ ), the gastrostomy tube is introduced through the sheath (c), The balloon is then inflated and the sheath is removed (d).

endoscopy room, with patients under conscious sedation, monitored by a pulse oximeter. Supplementary oxygen was used when necessary. Antibiotic prophylaxis was not used. For conscious sedation variable doses of diazepam 5 to 10 $\mathrm{mg}$ or of midazolam 3 to $10 \mathrm{mg}$ associated or not to variable doses of meperidine 0 to $100 \mathrm{mg}$ were used. The authors used the staging scale proposed by the International Union Against Cancer $^{27}$. This study included patients with advanced head and neck tumors (Stage III or Stage IV) or with nonresectable recurrences. The data referring to the tumor site, staging, indication, complications and perioperative mortality were analyzed. This study was accepted and approved by the review board of the local institution. 


\section{RESULTS}

From February, 2003 to May, 2004 a 129 PEGs were performed under this technique. This study included 60 patients with nonresectable recurrences or advanced head and neck tumors.

The indication of a PEG was the fact that these patients could not be fed through the mouth. In 47 of the cases this was due to dysphagia; the second most frequent impediment was postoperative salivary fistulas (eight cases); followed by bronchoaspiration (four cases) and nasal regurgitation (one case). The age range was between 36 and 82 (median 57 years). There were 49 men and 11 women in this group (4.4:1).

In our series only 28 patients had had a tracheostomy.

Two patients with hypopharynx malignancies had active tumors, which caused stenosis and did not allow the endoscope to pass through. Therefore, endoscopic dilatation had to be performed before the PEG was implanted. Table 1 shows the anatomical sites of the tumors and their corresponding stages.

TABLE 1 - Anatomical site and clinical stages

\begin{tabular}{lccccc}
\hline & \multicolumn{3}{c}{ Stage grouping } & & Total \\
\cline { 2 - 5 } & Stage III & Stage IV & $\begin{array}{c}\text { Non } \\
\text { Stageable: }\end{array}$ & & \\
\hline Oral cavity $\dagger$ & 3 & 11 & -- & 4 & 18 \\
Hypopharynx & 1 & 10 & 1 & 2 & 14 \\
Oropharynx $\dagger$ & 2 & 8 & -- & 2 & 12 \\
Larynx & 4 & 6 & -- & 1 & 11 \\
Nasopharynx & 1 & 2 & 1 & -- & 4 \\
Paranasal sinuses & -- & 2 & -- & -- & 2 \\
Salivary glands & -- & 1 & -- & -- & 1 \\
\hline TOTAL & $\mathbf{1 1}$ & $\mathbf{4 0}$ & $\mathbf{2}$ & $\mathbf{9}$ & $\mathbf{6 2}$ \\
\hline
\end{tabular}

$\dagger$ Two patients with synchronic tumors, in the oral cavity and in the oropharynx $\$$ Cannot be assessed. Two patients had advanced disease, however there were no elements that could help define if they were stages III or IV

Four patients had a second metachronic tumor, since they had had their first head and neck neoplasms treated and under control for more than 6 months. Their anatomical sites can be found in Table 2 .

TABLE 2 - Metachronic tumors

\begin{tabular}{cc}
\hline First tumor (already treated) & Second tumor (current) \\
\hline Larynx & Nasopharynx \\
Larynx & Hypopharynx \\
Lip & Larynx \\
Oral cavity & Hypopharynx \\
\hline
\end{tabular}

All the patients received food on the same day, after they had effectively recovered from the sedation.

Morbidity and mortality related to this procedure are listed in Table 3. The most significant complication was respiratory failure in three patients and in all of them the PEG was successful. The respiratory failure of the first patient in this group was a result of respiratory depression caused by medication. This specific patient needed orotracheal intubation and was hospitalized in the intensive care unit for 6 days, before he finally died. The respiratory failure in the second patient was attributed to extrinsic compression caused by the tumor of the hypopharynx. Introducing the endoscope only made it worse. This patient was orotracheal intubated in the endoscopy room, the PEG was performed and then he was sent to the operation room for a tracheostomy. The third patient could not be intubated and a tracheostomy was executed in the endoscopy room.

There were three complications caused by infection. One case of pneumonia, and another of peristomal wound infection, both were successfully treated with systemic parenteral antibiotic therapy. A third infection-related complication was a case of peritonitis caused by the leakage of gastric secretion around the feeding tube, to the peritoneal cavity. This patient underwent laparotomy to adequate fixation of the gastric wall to the abdominal wall.

TABLE 3 - Procedure-related morbidity and mortality

\begin{tabular}{lccc}
\hline \multicolumn{1}{c}{ Morbidity } & \multicolumn{2}{c}{ Mortality } \\
\hline Respiratory failure & 3 & Respiratory failure & 1 \\
Pneumonia & 1 & & \\
Infection of the surgical & 1 & & \\
wound & 1 & & $\mathbf{1 ( 1 , 6 \% )}$ \\
Peritonitis & $\mathbf{6 ( 1 0 \% )}$ & & \\
\hline TOTAL & & & \\
\hline
\end{tabular}

\section{DISCUSSION}

PEGs are procedures that have been frequently performed worldwide, since being described in 1980 by Gauderer et al. ${ }^{10}$. Many others had been used it with small variations $\mathbf{s}^{13,17,20}$. Its widespread use is due to the fact that it is an easy procedure and results in low morbidity. It is also very convenient for administering food and medication at home.

Several authors ${ }^{3,12,30}$ have successfully performed PEGs in patients with tumors of the head and neck, using the pull technique proposed by Gauderer et al. ${ }^{10}$. The question under discussion is whether the technical options that do not require the passage of the tube through the oral cavity would be safer.

The first description of the technique for implanting a gastrostomy tube through alternative paths other than the oral cavity dates from 1967 and was performed by Jascalevich ${ }^{16}$ in dogs. In 1979 Sacks et al. ${ }^{26}$ did the same procedure in a patient and in 1981 Preshaw $^{22}$ reported on a series of 11 patients. These three authors did the gastrostomy percutaneously using radioscopy. Since then, in specially trained centers and with experts in interventional radioscopy some authors have performed this procedure in patients with tumors of the head and neck ${ }^{2,6}$. These authors advocate the advantage of the reduced risk of tumoral implantation in the surgical wound, as well as the reduced risk of postoperative infection, thus making antibiotic prophylaxis unnecessary.

There have been several reports of tumoral implantations in the surgical wound of PEGs performed according to the pull technique, in patients with malignant neoplasms 
of the head and neck. The incidence of this complication, previously unknown, has recently been established by Cruz et al. ${ }^{4}$ as being $0.92 \%$. Several authors have recommended the introducer technique for PEGs done in patients with tumors of the head and neck, in order to avoid this complication $^{1,4,9,28}$.

There is another technical variant in which the gastrostomy tube is introduced percutaneously under endoscopic view and, as a consequence, the tube does not go through the oral cavity. This variant was originally described in 1980 by Hashiba $1^{4}$. In 1984, this technique was standardized and publicized by Russell et al. ${ }^{24}$. It was later adopted by other authors who introduced some technical modifications ${ }^{17,20,23}$. All the PEGs included in our series used this method.

Two reports compare the pull technique to the introducer technique executed with the aid of endoscopy ${ }^{19,21}$. Their authors report that the latter is more technically difficult and results in higher complication rates. Another more recent study also compares these two techniques in patients with advanced cancer of the head and neck ${ }^{29}$. These authors used a system of fixating the gastric wall and they concluded that the introducer technique should be the method of choice in this patient population, since it is associated to a significant reduction of complications, when compared to PEGs performed according to the pull technique.

The purpose of the stitches is to make the procedure safer, relative to the leakage risk of the gastric content. In 1980, Hashiba ${ }^{14}$ was the first to describe the suture of the gastric wall. It was first performed in dogs and in a small series of ten patients. Some years later a larger series was presented ${ }^{15}$. Dormann et al. ${ }^{7}$ described a device that he used successfully in 27 patients and which seemed to make suturing easier. Other methods for fixating the stomach wall by means of T-shaped fixators ${ }^{6,29}$ or a Fogarty embolectomy catheter ${ }^{23}$ have also been described. Ours series uses a modified suture technique proposed in 1999 by Kiser et al. ${ }^{18}$. This suture technique uses low cost medical supplies that are frequently used and therefore, are readily available.
Additionally it is relatively easy to perform. We believe that this fixation is important, especially in patients with advanced neoplasms, whose nutritional status is usually poor. The stitches do not eliminate the need of a careful follow up, since one of the patients in ours series presented leakage of the gastric content into the abdominal cavity.

The use of antibiotic prophylaxis has been considered mandatory for PEGs performed according to the pull technique ${ }^{11,30}$ and several prospective randomized studies have confirmed this need ${ }^{8,25}$. Even with antibiotic therapy, the rate of local infections is not negligible since it ranges from nine to $12 \% \%^{8,21,25,29}$. Conversely, and when using this introducer technique, several authors consider a course of antibiotics unnecessary ${ }^{2,6}$. Antibiotic prophylaxis was not used in this study and the rate of local infection was considered low (1.6\%), and when present, was successfully treated with antibiotics.

There were three cases of respiratory failure during the PEG in our series, representing 5\% of the group and this complication is mentioned by Gibson et al. ${ }^{12}$. Patients with tumors of the head and neck which have not undergone a tracheostomy should be carefully evaluated for the purpose of determining the need of a preoperative procedure.

Morbidity and mortality rates resulting from the procedure described here fall within acceptable limits and indicate that it is a safe procedure. The data that is present here represent the initial experience with this method and express the initial phase of the learning curve. Therefore, the expectation is that even better results will be obtained as the learning curve advances.

\section{CONCLUSION}

The introducer technique is both feasible and safe as it can be performed in an outpatient clinic and the patient can receive a food on the same day. An additional benefit is that there is no need to administer antibiotic prophylaxis. Furthermore, this technique is associated to low morbidity and to acceptable mortality rates.

Campoli PMO, Ejima FH, Cardoso DMM, Barreto PAQ, Pires RD, Meneghini AJ, Curado MP, Oliveira JC, Mota OM. Gastrostomia endoscópica percutânea em pacientes com tumores avançados de cabeça e pescoço. ABCD Arq Bras Cir Dig 2007; 20(2):97-101.

RESUMO - Racional - A gastrostomia endoscópica percutânea executada conforme a técnica proposta por Gauderer et al., em 1980, tem sido freqüentemente utilizada em pacientes com tumores de cabeça e pescoço. Diversos autores relatam que ela, conhecida como técnica de "puxar", está associada a risco de implante de tumor na parede abdominal assim como risco bastante elevado de infecção na ferida operatória. Algumas variantes técnicas proporcionam melhores resultados, contudo existem dúvidas acerca da sua viabilidade técnica na prática diária. Objetivo - Verificar a exeqüibilidade, segurança e morbidade da gastrostomia endoscópica percutânea realizada por técnica padronizada e bem definida em pacientes com tumores avançados ou irressecáveis da cabeça e pescoço. Método - É descrita série consecutiva de pacientes com tumores avançados ou irressecáveis de cabeça e pescoço, incapazes de receber dieta por via oral, submetidos à gastrostomia endoscópica percutânea no setor de endoscopia digestiva de um hospital oncológico de referência terciária. As sondas foram implantadas pela técnica de punção compreendida de duas etapas principais. A primeira, consistiu na aplicação de dois pontos transfixantes com o propósito de fixar a parede anterior do estômago à parede abdominal. A segunda, introdução do tubo de gastrostomia por punção percutânea. Resultados - Foram realizadas 129 gastrostomias endoscópicas percutâneas e incluiu 60 pacientes. Todos foram liberados para receber dieta no mesmo dia. Morbidade operatória ocorreu em seis pacientes $(10 \%)$ e mortalidade relacionada ao procedimento foi verificada em um paciente (1,6\%). Conclusão -A gastrostomia endoscópica percutânea é exeqüível e segura, além de estar associada à baixa morbidade e aceitável mortalidade.

DESCRITORES - Cirurgia vídeo-assistida. Neoplasias de cabeça e pescoço. Gastrostomia. Técnicas de sutura. 


\section{REFERENCES}

1. Adelson RT, Ducic Y. Metastatic head and neck carcinoma to a percutaneous endoscopic gastrostomy site. Head Neck. 2005;27:339-43.

2. Beaver ME, Myers JN, Griffenberg L, Waugh K. Percutaneous fluoroscopic gastrostomy tube placement in patients with head and neck cancer. Arch Otolaryngol Head Neck Surg. 1998;124: 1141-4.

3. Chandu A, Smith AC, Douglas M. Percutaneous endoscopic gastrostomy in patients undergoing resection for oral tumors: a retrospective review of complications and outcomes. J Oral Maxillofac Surg. 2003;61:1279-84.

4. Cruz I, Mamel JJ, Brady PG, Cass-Garcia M. Incidence of abdominal wall metastasis complicating PEG tube placement in untreated head and neck cancer. Gastrointest Endosc. 2005;62:708-11.

5. Deitel M, Bendago M, Spratt EH, Burul CJ, To TB. Percutaneous endoscopic gastrostomy by the "pull" and "introducer" methods. Can J Surg. 1988;31:1024.

6. Dinkel HP, Beer KT, Zbaren P, Triller J. Establishing radiological percutaneous gastrostomy with balloon-retained tubes as an alternative to endoscopic and surgical gastrostomy in patients with tumours of the head and neck or oesophagus. Br J Radiol. 2002;75:371-7.

7. Dormann AJ, Glosemeyer R, Leistner U, Deppe H, Roggel R, Wigginghaus B, Huchzermeyer H. Modified percutaneous endoscopic gastrostomy (PEG) with gastropexy--early experience with a new introducer technique. Z Gastroenterol. 2000;38:933-8.

8. Dormann AJ, Wigginghaus B, Risius H, Kleimann F, Kloppenborg A, Rosemann J, Padel Y, Pohl R, Baum HH, Lübbesmeier A, Schwab J, Kühlkamp V, Gutjahr W, Lindenburger W, Schütz H, Huchzermeyer H. Antibiotic prophylaxis in percutaneous endoscopic gastrostomy (PEG)--results from a prospective randomized multicenter trial. Z Gastroenterol. 2000;38:229-34.

9. Foster JM, Filocamo P, Nava H, Schiff M, Hicks W, Rigual N, Smith J, Loree $\mathrm{T}$, Gibbs JF. The introducer technique is the optimal method for placing percutaneous endoscopic gastrostomy tubes in head and neck cancer patients. Surg Endosc. 2006;21:897-901.

10. Gauderer MW, Ponsky JL, Izant RJ. Gastrostomy without laparotomy: a percutaneous endoscopic technique. J Pediatr Surg. 1980;15:872-5.

11. Gençosmanoglu R, Koç D, Tözün N. Percutaneous endoscopic gastrostomy: results of 115 cases. Hepatogastroenterology. 2003;50:886-8.

12. Gibson SE, Wenig BL, Watkins JL. Complications of percutaneous endoscopic gastrostomy in head and neck cancer patients. Ann Otol Rhinol Laryngol. 1992;101:46-50.

13. Gómez NA, Alvarez Ludwig R, Mite A, Andrade JP, Alvarez JR, Vargas PE. Percutaneous endoscopic gastrotomy (GEP): designed reusable (NAGEP) for one time endoscopic technique. Experimental study in dogs. Acta Gastroenterol Latinoam. 2000;30:233-5.
14. Hashiba K. Technic for opening a gastrostomy under endoscopic control and manipulation. Rev Paul Med. 1980;95:37-8.

15. Hashiba K. Endoscopic gastrostomy. Endoscopy. 1987;19 (Suppl 1):23-4.

16. Jascalevich ME. Experimental trocar gastrostomy. Surgery. 1967;62:452-3.

17. Kadota T, Nakagawa K, Taguchi J, Ono H, Hiraide H, Tamakuma S, Ueno F. A simplified percutaneous endoscopic gastrostomy using the trocar introducer technique with peel-away sheath. Surg Gynecol Obstet. 1991;173:490-4.

18. Kiser AC, Inglis G, Nakayama DK. Primary percutaneous endoscopic button gastrostomy: a modification of the "push" technique. J Am Coll Surg. 1999;188:704-6.

19. Kozarek RA, Ball TJ, Ryan JA. When push comes to shove: a comparison between two methods of percutaneous endoscopic gastrostomy. Am J Gastroenterol. 1986;81:642-6.

20. Morioka RH, Mikami G, Onozato ML, Tacla Jr O, Godoy AQ, Fonseca PC, Komatsu S. Percutaneous endoscopic gastrostomy: a simples and effective technique for enteral nutrition. Rev Col Bras Cir. 1995;22:11-6.

21. Petersen TI, Kruse A. Complications of percutaneous endoscopic gastrostomy. Eur J Surg. 1997;163:351-6.

22. Preshaw RM. A percutaneous method for inserting a feeding gastrostomy tube. Surg Gynecol Obstet. 1981;152:658-60

23. Robertson FM, Crombleholme TM, Latchaw LA, Jacir NN. Modification of the "push" technique for percutaneous endoscopic gastrostomy in infants and children. J Am Coll Surg. 1996;182:215-8.

24. Russell TR, Brotman M, Norris F. Percutaneous gastrostomy. A new simplified and cost-effective technique. Am J Surg. 1984;148:132-7.

25. Saadeddin A, Freshwater DA, Fisher NC, Jones BJ. Antibiotic prophylaxis for percutaneous endoscopic gastrostomy for non-malignant conditions: a double-blind prospective randomized controlled trial. Aliment Pharmacol Ther. 2005;22:565-70

26. Sacks BA, Glotzer DJ. Percutaneous reestablishment of feeding gastrostomies. Surgery. 1979;85:575-6.

27. Sobin LH, Wittekind Ch. TNM classification of malignant tumours. 5th ed. New York: Wiley; 1997.

28. Thakore JN, Mustafa M, Suryaprasad S, Agrawal S. Percutaneous endoscopic gastrostomy associated gastric metastasis. J Clin Gastroenterol. 2003;37:30711.

29. Tucker AT, Gourin CG, Ghegan MD, Porubsky ES, Martindale RG, Terris DJ. 'Push' versus 'pull' percutaneous endoscopic gastrostomy tube placement in patients with advanced head and neck cancer. Laryngoscope. 2003;113:1898902.

30. Urban KG, Terris DJ. Percutaneous endoscopic gastrostomy by head and neck surgeons. Otolaryngol Head Neck Surg. 1997;116:489-92.

Conflito de interesse: não há

Fonte financiadora: não há

Recebido para publicação em: 17/01/2007

Aceito para publicação em: 20/04/2007 